\title{
THE PLACE OF THE APOCALYPSE IN THE CANON OF ST. GREGORY NAZIANZEN
}

\section{Frank Thielman}

After explicitly naming every other New Testament book but the Apocalypse, St. Gregory Nazianzen closes his poetical list of 'the genuine books of the inspired scripture' with the statement, 'You have all. And if there be any outside these, it is not among

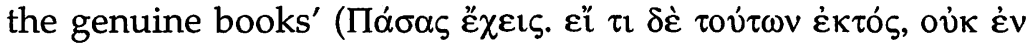
$\gamma v \eta$ fials). $^{1}$ Studies of the New Testament canon commonly understand the omission of any clear reference to the Apocalypse in the list and these definitive closing statements to mean that Gregory did not view the Apocalypse as canonical. ${ }^{2}$ If so, then Gregory, whose list comes from sometime in the 380 s, did not agree with Athanasius' judgement in his famous Easter letter of 367 but took the position of many in the fourthcentury eastern church that the Apocalypse stands among the excluded books. Three pieces of evidence, however, should caution against coming to this conclusion too hastily.

First, although the list does not mention the Apocalypse explicitly, it contains a clear allusion to it, and this allusion implies that Gregory believed the Apocalypse to be an apostolic document. The allusion comes directly after Gregory's list of the gospels and connects the Apocalypse with John's gospel:

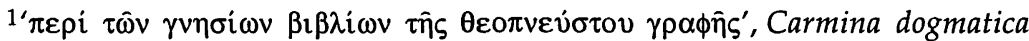
12.30-39 (PG 37.471-74).

${ }^{2}$ E.g. B.F. Westcott, A General Survey of the History of the New Testament Canon (6th ed.; New York: Macmillan, 1889) 446; E.J. Goodspeed, The Formation of the New Testament (Chicago: University of Chicago Press, 1926) 131, 169; and B.M. Metzger, The Canon of the New Testament: Its Origin, Development, and Significance (Oxford: Clarendon, 1987) 212. Cf. C.R. Gregory, Canon and Text of the New Testament (New York: Charles Scribner's Sons, 1907) 273-74, and G.M. Hahneman, The Muratorian Fragment and the Development of the Canon (Oxford: Clarendon, 1992) 24, 148-49, who both comment on Gregory's ommission of the Apocalypse but do not explicitly say that he excluded it from his canon.
} 
Now Matthew wrote the marvelous works of Christ to the Hebrews, and Mark to Italy, Luke to the Greeks, and John, great preacher, entrant of heaven (ovjpavoфoíths), to all. ${ }^{3}$

John enters heaven only in the Apocalypse, ${ }^{4}$ and so from this brief reference we can conclude that Gregory believed that John the apostle wrote both the fourth gospel and the Apocalypse. If Gregory considered the Apocalypse to be an apostolic document, however, it is difficult to see how he could have intended to include it in his statement at the end of the list that

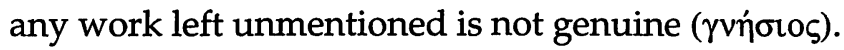

Second, it is possible that Gregory intended his reference to John as one who entered heaven to cover the Apocalypse. The reference closes Gregory's list of gospel writers and, if it refers to the Apocalypse, agrees with an ancient order of the New Testament books that placed the Apocalypse directly after the gospels. The Crawford Manuscript of the Peshitta (12th or 13th century), a Harclean manuscript (13th century), the New Testament commentary by Dionysius bar Salibĩ (12th century), the first printed edition of the Ethiopic version (16th century), and probably Codex Bezae (5th or 6th century) all locate the Apocalypse immediately after the four gospels, although not necessarily after John's gospel. ${ }^{5}$ This arrangement of the order of the books may have been known to Gregory and others in the fourth century, and, if so, Gregory may have assumed that his readers would recognize that the Apocalypse had been covered by his description of the author of the fourth gospel as 'an entrant of heaven'.

Third, Gregory uses the Apocalypse in his extant writings more frequently than is often recognized. Scholars who write on the New Testament canon frequently mention the

3PG 37.474. On the meaning of ov pavoфoi $\tau \eta$ s, see G.W.H. Lampe (ed.), $A$ Patristic Greek Lexicon (Oxford: Clarendon, 1961) s.v. The Lexicon points out that John of Damascus uses the same term to describe Elijah (de fide orthodoxa 4 [PG 94.789]).

${ }^{4}$ Rev. 4:1-2.

5See B.M. Metzger, 'Variations in the Sequence of the Books of the New Testament', in his Canon of the New Testament, 295 n. 1. 
'marked respect'6 with which Gregory refers to the Apocalypse in his one explicit reference to it outside his poem on the genuine books. In this reference, Gregory says that churches have their appointed angels 'as John teaches me through the

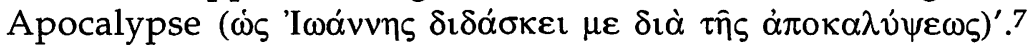
They also commonly say that Gregory makes one other obvious allusion to the Apocalypse. ${ }^{8}$ Allusions to the Apocalypse are, however, more frequent than this. Gregory uses the phrase 'new Jerusalem', 9 echoes the description of Christ as 'the first and the last', 10 and recalls the scene of judgement at the great white throne. 11

It is difficult to know why Gregory, if he considered the Apocalypse canonical, did not include an explicit reference to it in his poem on the genuine books. On the other hand, it is also difficult to understand why he would include among the inauthentic books a work that he considered apostolic and whose teaching and imagery he valued. The evidence is certainly not decisive for the view that Gregory regarded the Apocalypse as canonical. The evidence is ambiguous enough, however, that Gregory ought not to be listed without qualification as another fourth-century eastern Father who excluded the Apocalypse from the canon.

${ }^{6}$ Westcott (Canon, 446) and Hahneman (Muratorian Fragment, 149) both use the phrase of Gregory's reference to the Apocalypse in supremum vale 9 (PG 36.469).

${ }^{7}$ The allusion is to Rev. $2: 1,8,12,18 ; 3: 1,7$, and 14 , not as Westcott states (Canon, 446 n. 2), to Rev. 1:8.

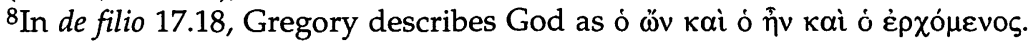
Cf. Rev. 1:8.

${ }^{9}$ Rev. 3:12; 21:12. Cf. funebris oratio in patrem 17 (PG 35.1005); contra Arianos

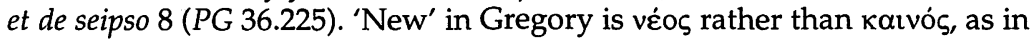
the Apocalypse.

10Rev. 1:17; 2:8; 22:13; Cf. in theophania 1 (PG 36.313).

${ }^{11}$ Rev. 20:11-15; Cf. ad Julianum tributorum exaequatorem 15 (PG 35.1061), 16 (PG 35.1064). 